\title{
The Readiness of Indonesia to Implement Blended Biodiesel B30
}

\author{
Hermawan Febriansyah ", Fajar Budi Utomo, and Suminto Suminto \\ Center of Research and Human Resources Development, National Standardization Agency \\ of Indonesia, Puspiptek Complex Building number 430, Tangerang Selatan 15314, Indonesia
}

\begin{abstract}
Since 2016, based on the regulation of the Minister of Energy and Mineral Resources number 12/2015, the government has enacted a policy of mixing biodiesel into diesel oil by $20 \%$, also known as B20. It is applied to all sectors that use diesel oil. In 2020, based on that regulation, Indonesia will continue to implement B30. Indonesia will be the first nation in the world to implement B30, especially biodiesel based on palm oil. This study is to present the readiness of Indonesia to implement B30 by the installed capacity, the regulation, the reference of standard, and the availability of biodiesel laboratory. This study is based on literature studies, discussion, and biodiesel testing. The result of this study showed that the biodiesel installed capacity has enough to supply B30. The regulation has available as mandatory starting per 2020. The biodiesel testing showed compliance in the parameter of the revised standard. The biodiesel laboratory as a conformity assessment also has available to test the revision of biodiesel standard. It gives confidence for Indonesia to implement B30.
\end{abstract}

Key words: Biodiesel standard, B30 regulation, biodiesel laboratory, biodiesel production capacity, palm oil blended biodiesel.

\section{Introduction}

Diesel oil is one of the most significant fuel needs in Indonesia. As of 2018, Indonesia consumes diesel oil by $30962670 \mathrm{~kL}$ [1]. Diesel oil can be supplied domestically is only $79 \%$ or $24460000 \mathrm{~L}$ of consumption, so diesel oil is needed to import. Now, domestic diesel oil users are the micro sector, fisheries, agriculture, transportation, services, general, power plants, industry, and commercial. From 2015 until 2018, there was an increase in diesel oil consumption by an average of $5 \%$ per year. Since 2016 , based on the regulation of the Minister of Energy and Mineral Resources number 12/2015, the government has enacted a policy of mixing biodiesel into diesel oil by $20 \%$, also known as B20 [2]. B20 is applied to all sectors that use diesel oil. In 2020, based on that regulation, Indonesia will continue to implement B30. Indonesia will be the first nation in the world to implement B30, especially biodiesel based on palm oil.

*Corresponding author: hermawan.febriansyah@bsn.go.id 
At present, the government is preparing a policy of mixing biodiesel to $30 \%$ or B30. The raw material for B30 is the same as B20, which comes from palm oil. To support this, the ESDM Ministry launched a B30 road test program on 13 June 2019. The program proposed for the approval of the B30 specification proposed as an SNI standard. SNI 7182: 2015 will be revised to become a B30 specification. If it is successfully implemented, Indonesia will become the first country in the world to use B30, and correctly, B30, made from palm oil. While for B20 until 2018, only three countries have implemented B20, namely the United States, Canada, and Indonesia. The United States and Canada have different standards from Indonesia because they do not use palm oil raw materials. The United States and Canada use soybean oil as raw material. This study is to present the readiness of Indonesia to implement B30 by the installed capacity, the regulation, the reference of standard, and the availability of biodiesel laboratory.

\section{Method}

This study is based on literature studies, discussion, and surveys. The literature studies are to obtain the secondary data of installed capacity, the applied regulation, the reference of standard, and the availability of biodiesel laboratory. The discussion is established by a forum group discussion that consisting of government, industry, and laboratory, and also by surveys to producers to obtain the primary data of installed capacity. The data is collected as per 30 August 2019. The tool of surveys is done by a questionnaire that consisting of 14 questions for producers listed in the regulation of minister of energy and mineral resources number $15 \mathrm{k} / 10 / \mathrm{MEM} / 2019$.

\section{Result and discussion}

\subsection{The capacity of biodiesel productions}

Until 2019, there are $12060000 \mathrm{~kL}$ of biodiesel have been installed in Indonesia. The production of biodiesel reached up to $6160000 \mathrm{~kL}$ in 2018. So the utilization of biodiesel production is about $51 \%$ [3]. If Indonesia applies B30 in 2030, the utilization of biodiesel production will reach about $75 \%$ from existing capacity. As shown in Figure 1, from survey to seven biodiesel producers shows that $43 \%$ of them have a plan to upsize the capacity of production for supply B30.

\section{Biodiesel Potential Growth Capacity in 2019}

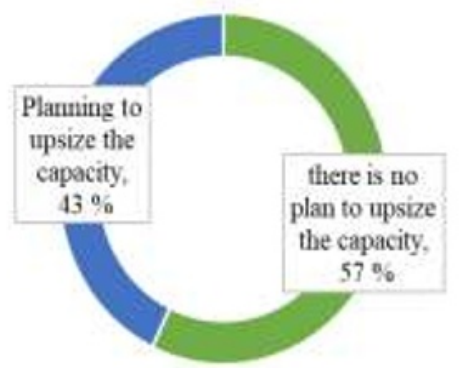

Fig. 1. Biodiesel's potential growth capacity in 2019 . 


\subsection{Regulation of diesel and biodiesel for blended biodiesel B30}

In implementing B30 in Indonesia, B30 is a working road test coordinated by the Minister of Energy and Mineral Resources. This road test is to evaluate the parameters of the standard to be implemented for B30. The existing diesel parameter is still available based on the regulation of the Director-General of Oil and Gas number 28.K/10/DJM.T/2016 and Director General of New Energy, Renewable and Energy Conservation Decree number 332K/10/DJE/2018 that only can implement with blended biodiesel B20 [4]. The quality of biodiesel for B20 is referenced to SNI 7182:2015. So, for blended biodiesel B30, the government has not issued the regulation yet.

\subsection{The draft of biodiesel standard for blended biodiesel B30}

To implement B30, the standard of B30 follows not only the result of road test B30 but also the readiness of the industry to produce the specification of biodiesel. In the discussion of revision SNI 7182:2015, the technical committee of bioenergy still in the debate of five parameters to be changed and six parameters to be added. Table 1 shows that the revision of SNI 7182:2015 will change the parameter of flashpoint, sulfur, acid value, oxidation stability, and monoglyceride. There is also add a parameter of water content, CFPP, metal $1(\mathrm{Na}+\mathrm{K})$, metal $2(\mathrm{Ca}+\mathrm{Mg})$, a total of contaminant, and color. Because Indonesia is one of the worlds to implement B30, the result of parameter biodiesel for B30 may be adopted by another country. Indonesia using palm oil as the raw material of biodiesel, so the other countries with different feedstocks may use a different standard. It also may cause difficulty in the harmonization of the biodiesel standard [10].

Table 1. The concern of the draft revision standard of SNI 7182 for B 30

\begin{tabular}{ccc}
\hline $\begin{array}{c}\text { The change of } \\
\text { parameter }\end{array}$ & The eliminated parameter & The additional parameter \\
\hline $\begin{array}{c}\text { Flash point } \\
\text { Sulphur }\end{array}$ & Cloud point & Water content \\
Acid value & & CFPP \\
Oxidation stability & Metal I $(\mathrm{Na}+\mathrm{K})$ \\
Monoglyceride & Metal II $(\mathrm{Ca}+\mathrm{Mg})$ \\
& Total of contaminant \\
& Color \\
\hline
\end{tabular}

Following the regulation of the Minister of Energy and Mineral Resources number 12/2015, users of B30 have now been applied for power plant industries. So, if B30 apply in 2020, it will obligate to all sector at the regulation. However, the problem is any doubt from users to apply B30. Engines issue is the one to be made uncertainty of users. The completion of B30 road test will show the engine performance after the use of B30. It also validates the draft revision of the biodiesel standard to be applied. 
Table 2. The draft revision standard of SNI 7182 for B30 roadtest

\begin{tabular}{|c|c|c|c|c|c|c|}
\hline No & Parameters & Value, $\min / \max$ & $\begin{array}{c}\text { SNI } \\
7182: 2015\end{array}$ & $\begin{array}{c}\text { Test } \\
\text { method }\end{array}$ & $\begin{array}{l}\text { Draft } \\
\text { revision of } \\
\text { standard }\end{array}$ & $\begin{array}{c}\text { Draft } \\
\text { revision of } \\
\text { test method }\end{array}$ \\
\hline 1 & Density at $40^{\circ} \mathrm{C}$ & $\mathrm{kg} \mathrm{m}^{-3}$ & 850 to 890 & $\begin{array}{c}\text { SNI } \\
7182: 2015\end{array}$ & 850 to 890 & $\begin{array}{c}\text { SNI } \\
7182: 2015\end{array}$ \\
\hline 2 & $\begin{array}{l}\text { Kinematic viscosity } \\
\text { at } 40{ }^{\circ} \mathrm{C}\end{array}$ & $\mathrm{mm}^{2} \mathrm{~s}^{-1}(\mathrm{cSt})$ & 2.3 to 6.0 & $\begin{array}{c}\text { SNI } \\
7182: 2015\end{array}$ & 2.3 to 6.0 & $\begin{array}{c}\text { SNI } \\
7182: 2015\end{array}$ \\
\hline 3 & Cethane number & $\min$ & 51 & $\begin{array}{c}\text { SNI } \\
7182: 2015\end{array}$ & 51 & $\begin{array}{c}\text { SNI } \\
7182: 2015\end{array}$ \\
\hline 4 & Flashpoint & ${ }^{\circ} \mathrm{C}, \min$ & 100 & $\begin{array}{c}\text { SNI } \\
7182: 2015\end{array}$ & 130 & $\begin{array}{c}\text { SNI } \\
7182: 2015\end{array}$ \\
\hline 5 & $\begin{array}{l}\text { Copper Corrosion } \\
\left(3 \mathrm{~h} \text { at } 50{ }^{\circ} \mathrm{C}\right)\end{array}$ & & No. 1 & $\begin{array}{c}\text { SNI } \\
7182: 2015\end{array}$ & No. 1 & $\begin{array}{c}\text { SNI } \\
7182: 2015\end{array}$ \\
\hline 6 & $\begin{array}{l}\text { Carbon residue } \\
\text { - into sample; or } \\
\text { - into the rest of } \\
\text { distilation }\end{array}$ & $\%$-mass, max & $\begin{array}{c}0.05 \\
0.3\end{array}$ & $\begin{array}{c}\text { SNI } \\
7182: 2015\end{array}$ & $\begin{array}{c}0.05 \\
0.3\end{array}$ & $\begin{array}{c}\text { SNI } \\
7182: 2015\end{array}$ \\
\hline 7 & $\begin{array}{l}\text { Distillation } \\
\text { temperature } 90 \%\end{array}$ & ${ }^{\circ} \mathrm{C}, \max$ & 360 & $\begin{array}{c}\text { SNI } \\
7182: 2015\end{array}$ & 360 & $\begin{array}{c}\text { SNI } \\
7182: 2015\end{array}$ \\
\hline 8 & Ash sulphated & $\%$-mass, max & 0.02 & $\begin{array}{c}\text { SNI } \\
7182: 2015\end{array}$ & 0.02 & $\begin{array}{c}\text { SNI } \\
7182: 2015\end{array}$ \\
\hline 9 & Sulfur content & $\operatorname{mg~kg}{ }^{-1}, \max$ & 50 & $\begin{array}{c}\text { SNI } \\
7182: 2015\end{array}$ & 10 & $\begin{array}{c}\text { SNI } \\
7182: 2015\end{array}$ \\
\hline 10 & Phosphor & $\operatorname{mg~kg}{ }^{-1}, \max$ & 4 & $\begin{array}{c}\text { SNI } \\
7182: 2015\end{array}$ & 4 & $\begin{array}{c}\text { SNI } \\
7182: 2015\end{array}$ \\
\hline 11 & Acid value & $\underset{\max }{\mathrm{mg}-\mathrm{KOH} \mathrm{g}} \mathrm{g}^{-1}$, & 0.5 & $\begin{array}{c}\text { SNI } \\
7182: 2015\end{array}$ & 0.4 & $\begin{array}{c}\text { SNI } \\
7182: 2015\end{array}$ \\
\hline 12 & Free glycerol & $\%$-mass, max & 0.02 & $\begin{array}{c}\text { SNI } \\
7182: 2015\end{array}$ & 0.02 & $\begin{array}{c}\text { SNI } \\
7182: 2015\end{array}$ \\
\hline 13 & Total glycerol & $\%$-mass, max & 0.24 & $\begin{array}{c}\text { SNI } \\
7182: 2015\end{array}$ & 0.24 & $\begin{array}{c}\text { SNI } \\
7182: 2015\end{array}$ \\
\hline 14 & Ester methyl & $\%$-mass, min & 96.5 & $\begin{array}{c}\text { SNI } \\
7182: 2015\end{array}$ & 96.5 & $\begin{array}{c}\text { SNI } \\
7182: 2015\end{array}$ \\
\hline 15 & Iodine value & $\begin{array}{c}\% \text {-mass } \\
\left(\mathrm{g}-\mathrm{I}_{2} 100^{-1} \mathrm{~g}^{-1}\right), \\
\max \end{array}$ & 115 & $\begin{array}{c}\text { SNI } \\
7182: 2015\end{array}$ & 115 & $\begin{array}{c}\text { SNI } \\
7182: 2015\end{array}$ \\
\hline 16 & $\begin{array}{l}\text { Oxidation stability } \\
\text { Period of induction } \\
\text { with rancimat } \\
\text { method or Period of } \\
\text { induction with } \\
\text { petro-oxy method }\end{array}$ & Minute & $\begin{array}{r}480 \\
36\end{array}$ & $\begin{array}{c}\text { SNI } \\
7182: 2015\end{array}$ & $\begin{array}{l}600 \\
45\end{array}$ & $\begin{array}{c}\text { SNI } \\
7182: 2015\end{array}$ \\
\hline 17 & Monoglyceride & $\%$-mass, $\max$ & 0.8 & $\begin{array}{c}\text { SNI } \\
7182: 2015\end{array}$ & 0.55 & $\begin{array}{l}\text { ASTM D } \\
6584\end{array}$ \\
\hline 18 & Water Content & $\mathrm{mg} \mathrm{kg}^{-1}$, max & - & - & 350 & $\begin{array}{l}\text { ASTM D } \\
6304\end{array}$ \\
\hline 19 & $\begin{array}{l}\text { Cold Filter } \\
\text { Plugging Point } \\
\text { (CFPP) }\end{array}$ & ${ }^{\circ} \mathrm{C}, \max$ & - & - & 15 & $\begin{array}{c}\text { ASTM D } \\
6371\end{array}$ \\
\hline
\end{tabular}


Table 2. Continued

\begin{tabular}{|c|c|c|c|c|c|c|}
\hline No & Parameters & Value, $\min / \max$ & $\begin{array}{c}\text { SNI } \\
7182: 2015\end{array}$ & $\begin{array}{c}\text { Test } \\
\text { method }\end{array}$ & $\begin{array}{c}\text { Draft } \\
\text { revision of } \\
\text { standard }\end{array}$ & $\begin{array}{c}\text { Draft } \\
\text { revision of } \\
\text { test method }\end{array}$ \\
\hline 20 & Metal I $(\mathrm{Na}+\mathrm{K})$ & $\operatorname{mg~kg}{ }^{-1}, \max$ & - & - & 5.0 & $\begin{array}{c}\text { EN } \\
14108 / 14109, \\
\text { EN } 14538\end{array}$ \\
\hline 21 & Metal II $(\mathrm{Ca}+\mathrm{Mg})$ & $\mathrm{mg} \mathrm{kg}^{-1}$, max & - & - & 5.0 & EN 14538 \\
\hline 22 & $\begin{array}{l}\text { Total of } \\
\text { Contaminant }\end{array}$ & $\mathrm{mg} \mathrm{L}^{-1}$, max & - & - & 20 & $\begin{array}{c}\text { ASTM D } \\
2276, \text { ASTM } \\
\text { D 5452, } \\
\text { ASTM D } \\
6217\end{array}$ \\
\hline 23 & Color & & - & - & 3 & $\begin{array}{c}\text { ASTM D } \\
1500\end{array}$ \\
\hline 24 & Ash content & $\%$-volume & - & - & 0.01 & ASTM D 482 \\
\hline 25 & Cloud Point & ${ }^{\circ} \mathrm{C}, \max$ & 18 & $\begin{array}{c}\text { SNI } \\
7182: 2015\end{array}$ & - & - \\
\hline 26 & $\begin{array}{l}\text { Water and } \\
\text { sediment }\end{array}$ & $\%$-volume, $\max$ & 0.05 & $\begin{array}{c}\text { SNI } \\
7182: 2015\end{array}$ & - & - \\
\hline
\end{tabular}

The revision of the biodiesel standard is proposed to add more requirements to support B30. As shown in Table 2, the revision of the biodiesel standard has more requirements than SNI 7182:2015. The revision of biodiesel needs passing 23 tests to conform to the quality of biodiesel for B30. To know the competitiveness of biodiesel, the draft revision of biodiesel standard compared to European Standard of EN 14214:2012+A1:2014 (Table 3), Indonesia has a higher parameter than the European standard. From 24 parameters in the draft revision of the biodiesel standard, the European standard only matched 16 parameters to Indonesia Standard. Moreover, from 16 parameters of matched biodiesel standard, Indonesia has a higher standard for six parameters, there are acid value, total glycerol, iodine value, monoglyceride, water content, and total contaminant.

Table 3. Comparison the biodiesel standard between Europe and Indonesia

\begin{tabular}{|c|c|c|c|c|}
\hline No & Parameters & $\begin{array}{l}\text { Value, } \\
\min / \mathbf{m a x}\end{array}$ & $\begin{array}{c}\text { EN } \\
\text { 14214:2012+A1:2014 }\end{array}$ & $\begin{array}{l}\text { Draft revision of } \\
\text { SNI } 7182\end{array}$ \\
\hline 1 & Density at $40{ }^{\circ} \mathrm{C}$ & $\mathrm{kg} \mathrm{m}^{-3}$ & 860 to 890 & 850 to 890 \\
\hline 2 & Kinematic viscosity at $40^{\circ} \mathrm{C}$ & $\mathrm{mm}^{2} \mathrm{~s}^{-1}(\mathrm{cSt})$ & 3.5 to 5.0 & 2.3 to 6.0 \\
\hline 3 & Cethane number & $\min$ & 51 & 51 \\
\hline 4 & Flash point & ${ }^{\circ} \mathrm{C}$, min & 101 & 130 \\
\hline 5 & $\begin{array}{l}\text { Copper Strip Corrosion } \\
\left(3 \mathrm{~h} \text { at } 50^{\circ} \mathrm{C}\right)\end{array}$ & & No. 1 & No. 1 \\
\hline 6 & $\begin{array}{l}\text { Carbon residue } \\
\text { - into sample; or } \\
\text { - into the rest of distilation }\end{array}$ & $\%$-mass, $\max$ & - & $\begin{array}{c}0.05 \\
0.3\end{array}$ \\
\hline 7 & $\begin{array}{l}\text { Distillation temperature } 90 \% \\
\text { vol }\end{array}$ & ${ }^{\circ} \mathrm{C}, \max$ & - & 360 \\
\hline 8 & Sulfated ash & $\%$-mass, max & 0.02 & 0.02 \\
\hline
\end{tabular}


Table 3. Continued

\begin{tabular}{|c|c|c|c|c|}
\hline No & Parameters & $\begin{array}{l}\text { Value, } \\
\min / \mathbf{m a x}\end{array}$ & $\begin{array}{c}\text { EN } \\
\text { 14214:2012+A1:2014 }\end{array}$ & $\begin{array}{l}\text { Draft revision of } \\
\text { SNI } 7182\end{array}$ \\
\hline 9 & Sulfur content & $\mathrm{mg} \mathrm{kg}^{-1}, \max$ & 10 & 10 \\
\hline 10 & Phosphor & $\operatorname{mg~kg}{ }^{-1}, \max$ & 4 & 4 \\
\hline 11 & Acid value & $\underset{\max }{\operatorname{mg}-\mathrm{KOH} \mathrm{g}^{-1},}$ & 0.5 & 0.4 \\
\hline 12 & Free gliserol & $\%$-mass, $\max$ & 0.02 & 0.02 \\
\hline 13 & Total gliserol & $\%$-mass, max & 0.25 & 0.24 \\
\hline 14 & Ester methyl & $\%$-mass, min & 96.5 & 96.5 \\
\hline 15 & Iodine value & $\begin{array}{c}\% \text {-mass } \\
\left(\mathrm{g}-\mathrm{I}_{2} 100^{-1}\right. \\
\left.\mathrm{g}^{-1}\right), \max \\
\end{array}$ & 120 & 115 \\
\hline
\end{tabular}

\subsection{The effect of handling to keep biodiesel quality}

Biodiesel producers have procedures to distribute biodiesel. Some of the biodiesel producers have rules for each shipment; the transporter of biodiesel must have nitrogen blanket facility. They have a reason; the nitrogen blanket would affect the quality of biodiesel. Nitrogen blanket will keep the biodiesel quality to be changed, especially water content quality. It also makes a safe shipment. So some of them recommend standardizing the handling of biodiesel. For shipment with vessel, they found there were any changes for the water content of biodiesel up to $150 \mathrm{mg} \mathrm{kg}^{-1}$. Not only that, but biodiesel producers also found there was the different value of biodiesel quality tested in the discharge point. Some of them doubt about how the third parties or customers handle the biodiesel sample. As shown in Figure 2, biodiesel producers give recommendations the standardize the test of samples in the discharge point.

Indonesia has already released a reference in handling biodiesel. It is contained in the General Guidelines for Handling and Storage of Biodiesel Fuel (B100) and Biodiesel Mixtures (BXX) issued in 2018. In this guideline, it has been recommended to store in an oxygen-free steam chamber, for example, is using nitrogen blankets. However, because the guideline is not mandatory, it needs to be standardized or regulated so that it can be applied consistently [6]. This is also supported by guidelines for handling biodiesel from other countries. One of them is released by United States (U.S). Biodiesel Handling and Use Guide (Fifth Edition), which made by U.S. Department of Energy, also recommends the use of nitrogen blankets in biodiesel storage [11].

Earl Christensen in [9] has studied the stability of biodiesel and biodiesel blends. They did the experiment to test the biodiesel sample with a nitrogen blanket and stored it in a dark room at room temperatures. The study based on the long-term storage stability of biodiesel and biodiesel blends, [9] did fuel aging experiment. The study showed that a nitrogen blanket could reduce the oxidation of biodiesel [9]. 


\section{Standardization of handling and testing for biodiesel sample in discharge point}

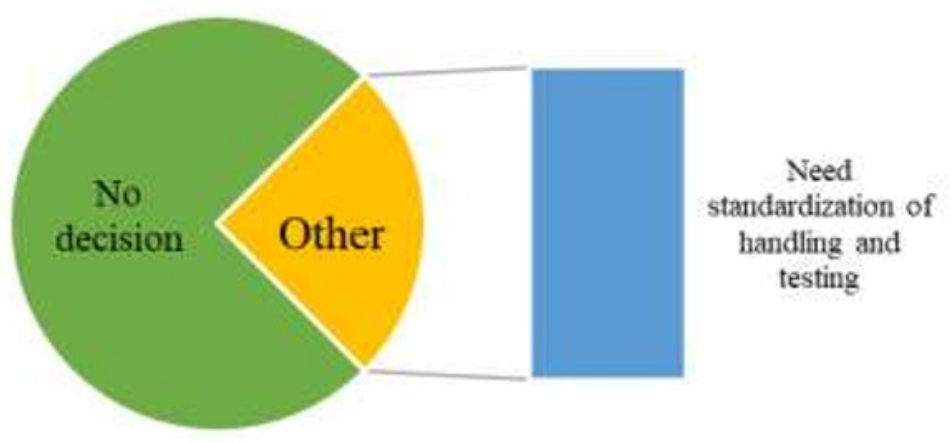

Fig 2. Biodiesel producers recommend standardizing the handling and testing of biodiesel.

\subsection{The availability of biodiesel laboratory}

For the biodiesel testing laboratory, Indonesia has six laboratories listed in the National Accreditation Committee of Indonesia; there are PPPTMGB "Lemigas," PT Sucofindo (Persero), PT Tekenomiks Indonesia, PT Pertamina (Persero) terminal BBM Manggis, LPPM IPB, and PT Wilmar Nabati Indonesia. However, only PPPTMGB "Lemigas" can test the biodiesel for full parameter [5]. All of the biodiesel producers have biodiesel laboratory, but some of them only can test biodiesel partially. In many cases, the biodiesel producers test biodiesel in another country for export.

\section{Conclusion}

The result presented that biodiesel producers ready to implement B30 based on their production capacity. In 2018, Indonesia consumes $3750066 \mathrm{~kL}$, still $31 \%$ of 12059369 $\mathrm{kL}$ of installed capacity. The Standard of biodiesel has not been finished revision yet, and also the standard or regulation of diesel oil needed to be revise because it only applies to B20. The testing laboratories as one of quality infrastructure are available and ready to provide testing for biodiesel.

The author would like to thank the Minister of Research, Technology, and High Degree to support the research by the program of Insentif Riset Nasional (Insinas) contract number 05/INS-1/PPK/E4/2019.

\section{References}

1. General directorate of oil and gas. Laporan tahunan capaian pembangunan 2018 [Annual report on development achievements 2018] [Online] from https://migas.esdm.go.id/uploads/uploads/files/laporan-tahunan/Laptah-Migas-2018--FINAL.pdf. [Accessed on 9 March 2020] 
2. Minister of Energy and Mineral Resources. Peraturan Menteri Energi dan Sumber Daya Mineral nomor 12 tahun 2015 tentang perubahan ketiga atas peraturan menteri energi dan sumber daya mineral nomor 32 tahun 2008 tentang penyediaan, pemanfaatan, dan tata niaga bahan bakar nabati (biofuel) sebagai bahan bakar lain [Regulation of the Minister of Energy and Mineral Resources number 12 of 2015 concerning the third amendment to the regulation of the Minister of energy and mineral resources number 32 of 2008 concerning the supply, utilization, and administration of biofuels as other fuels] [Online] from https://jdih.esdm.go.id/storage/document/Permen\%20ESDM\%2012\%20Thn\%202015. pdf (2015). [Accessed on 31 August 2019].

3. Ministry of Energy and Mineral Resources. FAQ: Program mandatori biodiesel 30\% (B30) [FAQ: Mandatory biodiesel $30 \%$ program] [Online] from http://ebtke.esdm.go.id/post/2019/12/19/2434/faq.program.mandatori.biodiesel.30.b30 [Accessed on 22 March 2020].

4. Director-General of New Energy, Renewable and Energy Conservation Decree number $332 \mathrm{~K}$. Standard and quality of biodiesel as alternative energy in domestic market. (2018). (not published)

5. KAN. Direktori klien laboratorium penguji [Directory of testing laboratory clients] [Online] from http://www.kan.or.id/index.php/documents/terakreditasi/doc17020/sniiso-iec-17025/laboratorium-penguji _[Accessed on 31 August 2019].

6. Ministry of energy and mineral resources. General guidelines of handling and storage of biodiesel (B100) and blended biodiesel (BXX) [Online] from http://ebtke.esdm.go.id/download/index/f6ffeb095cbe1ff4a12053a600bba9d0 (2018) [Accessed on 31 August 2019]

7. National Standardization Agency of Indonesia. SNI 7182:2015: Biodiesel. Indonesia, National Standardization Agency of Indonesia (2015). pp. 1-87. http://sispk.bsn.go.id/SNI/DetailSNI/10147

8. British Standards Institution. EN 14214:2012+A1:2014. Liquid petroleum productsFatty acid methyl esters (FAME) for use in diesel engines and heating applicationsRequirements and test methods. UK, British Standards Institution (2014). pp. 1-21. https://www.thenbs.com/PublicationIndex/documents/details?Pub=BSI\&DocID=3242 $\underline{42}$

9. E. Christensen, R.L. McCormick. J. Fuel Process. Technol., 128:339-348(2014). https://www.sciencedirect.com/science/article/pii/S0378382014003361

10. O.S. Tyagi, N. Atray, B. Kumar, A. Datta. J. Metrology Society of India, 25,3:197218(2010). https://link.springer.com/article/10.1007/s12647-010-0018-6

11. T.L. Alleman, R.L. McCormick. Biodiesel handling and use guide. 5th ed. USA, U.S. Department of Energy (2016). p. 16. https://afdc.energy.gov/files/u/publication/biodiesel_handling_use_guide.pdf 